\title{
Patient Satisfaction with the Work of Nurses in Primary Health Care
}

1 Jasminka Franjo

2 Slađana Režić

${ }^{3}$ Boris Tot

1 Health Centre of the Ministry of the Interior of the Republic of Croatia, Zagreb, Croatia

2 Department for Health Care Quality Assurance and Improvement, UHC Zagreb, Croatia

${ }^{3}$ Ministry of the Interior of the Republic of Croatia, Zagreb, Croatia

Article received: 04.11.2019.

Article accepted: 14.01.2020.

DOI: $10.24141 / 2 / 4 / 1 / 1$

Author for correspondence:

Jasminka Franjo

Health Centre of the Ministry of the Interior

of the Republic of Croatia

Šarengradska 3, Zagreb, Croatia

E-mail: jasminka.franjo4@gmail.com

Keywords: nurses in primary health care, patient satisfaction, questionnaires for the measurement of patient satisfaction

\section{Abstract}

Introduction. Patient satisfaction with provided health care is an important indicator of health care quality. Research on patient satisfaction has been very frequent in recent years.

Aim. A prospective, cross-sectional study was conducted at the Health Centre of the Ministry of the Interior of the Republic of Croatia between April and June 2019. The aim of this study was to examine the satisfaction of patients with the work of nurses in primary health care.

Methods. A standardized Nursing Practitioner Satisfaction Survey questionnaire, for which we received the author's approval, was used. The study involved 200 patients from the Health Centre of the Ministry of the Interior of the Republic of Croatia. Patients who came to the Health Centre's outpatient clinics requiring only the services of nurses were included in the study. Out of 200 patients surveyed, 185 questionnaires were filled out correctly, while 15 were filled out incorrectly.

Results. Patients from the Health Centre of the Ministry of the Interior of the Republic of Croatia are satisfied with the work of nurses in primary health care. There is no statistically significant difference in the satisfaction with the work of nurses in primary health care according to gender, education, marital or working status. There is a statistically significant difference in patient satisfaction with the work of nurses according to the respondents' age, where re- 
spondents in the age group between 26 and 40 years are less satisfied (Kruskal-Wallis test, $\mathrm{Me}=3.8$ ). There is a statistically significant difference in the satisfaction of patients with the work of nurses in primary health care according to the respondents' annual income, where satisfaction is more pronounced among respondents with an annual income between 26.000 to $35.000 \mathrm{HRK}$ and in the range between 36.000 to 45.000 HRK (Kruskal-Wallis test, $p<0.01$ ).

Conclusion. The patients who took part in the study are satisfied with the work of nurses in primary health care. There are significant differences in terms of age and annual income.

\section{Introduction}

Public health care in the Republic of Croatia is implemented on the basis of the principles of comprehensiveness, continuity, accessibility and a holistic approach in primary health care, as well as a specialized approach in specialist care and hospital health care (1).

It is the responsibility of the health care institution to monitor how well patients' rights are respected. Also, every health care institution is required to conduct regular surveys of patient experience and satisfaction (2). Patient satisfaction with provided health care is an important indicator of health care quality. Research on patient satisfaction has been very frequent in recent years. The problem is the interpretation of results, which can be complex and depends on the research instruments.

According to article 7 ("Patients' Rights and Experiences, Staff Satisfaction") of the Ordinance on Health Care Quality Standards and the Methods of their Implementation, adopted by the Ministry of Health and Social Welfare on 29 June 2011, a health care provider must ensure that every patient can exercise their rights when receiving health care services and must also implement all necessary measures to protect these rights in accordance with applicable regulations. This includes assessing how well the patients' rights are respected by regularly surveying their experiences and satisfaction once a year and analysing the results (2).
For hospitals, the Ordinance on Accreditation Standards specifies the systematic planning and implementation of processes for the measurement, monitoring and analysis of specific areas, and one of the areas is patient experience and satisfaction (3).

Patient satisfaction is increasingly used as an indicator of quality in the health care system, although it is a patient's subjective experience. The involvement of patients in the improvement of health care is desirable, and according to the World Health Organization, socially, economically and technically important (4). Many studies have shown that patients rate nurses based on their kindness, friendliness, ability to solve an immediate problem, as well as their medical skills (5). Patient satisfaction is defined as the difference between a patient's expectations and their experiences as the user of nursing services. A nurse who wants to provide quality service and satisfy their patients must first understand their patients' needs and anticipate their expectations (5).

Monitoring health care satisfaction is common practice in many countries. There is no golden standard for the measurement of patient satisfaction. Initially, the EUROPEP instrument was developed to compare the general health care work in Europe as a whole that would provide educational feedback to family physicians and patients (6). Research is being conducted to improve health care, which includes:

- reducing waiting times for medical examinations

- data protection and confidentiality

- providing fast services in cases of emergency (6)

- improvements in service quality and care provided

- providing preventive care

- patient decision-making in the treatment and delivery of health care (7)

- health system reforms focused on strengthening primary care and streamlining hospital care (8).

\section{Aim}

The aim of this study is to examine the satisfaction of patients with the work of nurses in primary health care. 
The specific aims of the study are to determine whether there are differences in patient satisfaction with the work of nurses in primary health care according to the demographic characteristics of patients (age, gender, education, marital status), employment and annual income.

\section{Methods}

\section{Participants}

The study involved 200 patients from the Health Centre of the Ministry of the Interior of the Republic of Croatia. Out of the 200 surveyed patients, 185 questionnaires were included in the analysis because 15 questionnaires were not filled in correctly. Of the total number of respondents, 126 (68.1\%) were male and 59 were female (31.9\%). Most respondents belonged to the age group between 41 and $60(\mathrm{~N}=85 ; 45.9 \%)$. Patients of over 18 years of age who came to the Health Centre's outpatient clinics requiring only nursing services were included in the study. Patients were asked by the clinic nurse whether they would like to participate in the survey, after which they signed a consent form. A room was provided for them to fill in the questionnaire. The average questionnaire fill-in time was 5 minutes. The study was conducted at the Health Centre of the Ministry of the Interior of the Republic of Croatia between 1 April and 30 June 2019.

\section{Instrument}

As the research instrument, we used the standardized questionnaire "Nurse Practitioner Satisfaction Survey" (NPSS), which examines the satisfaction of patients with the service provided by nurses, for which we received the author's approval (14). The first part of the questionnaire included demographic information such as gender, age, education, marital status, employment and annual income, as well as patient health information such as the assessment of disease and injury for which medications were being taken and the number of prescription medications, number of annual visits to the nurse and type of health insurance. The second part of the question- naire contained patient satisfaction rating scales. The scale consisted of 26 items; 18 items pertained to patient satisfaction, 4 items pertained to communication and 4 items pertained to availability. Every item was marked between 1 and 5 on the Likert scale, with 1 meaning complete disagreement and 5 meaning complete agreement.

\section{Statistics}

Category data is displayed in absolute and relative frequencies. Numerical data is described by median and interquartile ranges. The normality of the individual domain distributions and the overall scale was examined by the Kolmogorov-Smirnov test, and the results showed a statistically significant deviation from the normal distribution $(p<0.01)$. Therefore, differences between the examined variables for the two independent groups were examined by the Mann-Whitney $U$ test, and by the Kruskal-Wallis test between three and more independent groups. The SPSS for Windows 15.0 computer software package was used for statistical processing and analysis.

\section{Results}

\section{Respondents' basic characteristics}

The study was conducted on 185 respondents, among which 126 (68.1\%) were male and 59 female (31.9\%). Most respondents belonged to the age group of between 41 and $60(\mathrm{~N}=85 ; 45.9 \%)$ and most had secondary education ( $\mathrm{N}=137 ; 74.1 \%)$. Regarding their marital status, most respondents were married ( $\mathrm{N}=107 ; 57.8 \%)$. A majority of respondents were employed full-time $(\mathrm{N}=136 ; 73.5 \%)$ and most had an annual income of above 60.000 HRK ( $N=113$; $61.1 \%)$. Most respondents answered that they were not sick, 116 (62.7\%) (Table 1).

\section{Respondents' perception of their health status}

Most of the respondents in the sample had no injuries at the time of the survey ( $N=156 ; 84.3 \%)$. The most common health issues for which respondents 


\begin{tabular}{|c|c|c|c|}
\hline \multicolumn{2}{|c|}{ Respondents' characteristics } & \multirow{2}{*}{$\begin{array}{c}\text { Number of } \\
\text { respondents } \\
126\end{array}$} & \multirow{2}{*}{$\begin{array}{c}\begin{array}{c}\% \text { of } \\
\text { respondents }\end{array} \\
68.1\end{array}$} \\
\hline \multirow{2}{*}{ Gender } & Male & & \\
\hline & Female & 59 & 31.9 \\
\hline \multirow{4}{*}{$\begin{array}{c}\text { Age } \\
\text { (in years) }\end{array}$} & $18-25$ & 33 & 17.8 \\
\hline & $26-40$ & 47 & 25.4 \\
\hline & $41-60$ & 85 & 45.9 \\
\hline & Over 60 & 20 & 10.8 \\
\hline \multirow{4}{*}{ Level of education } & Primary & 3 & 1.6 \\
\hline & Secondary & 137 & 74.1 \\
\hline & Tertiary (Bachelor) & 18 & 9.7 \\
\hline & Tertiary (Master) & 27 & 14.6 \\
\hline \multirow{6}{*}{ Marital status } & Single & 37 & 20.0 \\
\hline & Married & 107 & 57.8 \\
\hline & Divorced & 14 & 7.6 \\
\hline & Widowed & 7 & 3.8 \\
\hline & Life partnership & 8 & 4.3 \\
\hline & Other & 12 & 6.5 \\
\hline \multirow{7}{*}{ Employment status } & Unemployed & 26 & 14.1 \\
\hline & Employed full-time & 136 & 73.5 \\
\hline & Employed part-time & 1 & 0.5 \\
\hline & Temporarily employed & 5 & 2.7 \\
\hline & Retired & 13 & 7.0 \\
\hline & Self-employed & 3 & 1.6 \\
\hline & Other & 1 & 0.5 \\
\hline \multirow{6}{*}{$\begin{array}{l}\text { Annual income } \\
\text { (in HRK) }\end{array}$} & less than 15.000 & 37 & 20.0 \\
\hline & $15.000-25.000$ & 1 & 0.5 \\
\hline & $26.000-35.000$ & 10 & 5.4 \\
\hline & $36,000-45,000$ & 5 & 2.7 \\
\hline & $46.000-55.000$ & 19 & 10.3 \\
\hline & More than 60.000 & 113 & 61.1 \\
\hline \multirow{4}{*}{ How sick are they on this day } & very sick & 6 & 3.2 \\
\hline & moderately sick & 24 & 13.0 \\
\hline & slightly sick & 39 & 21.1 \\
\hline & not sick & 116 & 62.7 \\
\hline
\end{tabular}

were receiving medication are blood pressure-related issues ( $N=35 ; 18.9 \%)$, followed by issues related to other diseases $(\mathrm{N}=26 ; 14.1 \%)$, high cholesterol level $(\mathrm{N}=13 ; 7.0 \%)$, heart disease $(\mathrm{N}=10 ; 5.4 \%)$ and depression/anxiety $(\mathrm{N}=9 ; 4.9 \%)$. Most respond- ents take two prescription drugs ( $\mathrm{N}=166 ; 89.7 \%)$ and most are holders of health insurance $(\mathrm{N}=179$; $96.8 \%)$. In the previous year, most respondents visited a nurse up to 5 times ( $\mathrm{N}=152 ; 82.2 \%)$ (Table 2). 
Table 2. Respondents' perception of their health status ( $N=185)$

Respondents' characteristics

Number of

$\%$ of

respondents

respondents

\begin{tabular}{cccc} 
& very injured & 2 & 1.1 \\
How injured they are on this day & mildly injured & 10 & 5.4 \\
& slightly injured & 17 & 9.2 \\
& uninjured & 156 & 84.3 \\
Health issues & High blood pressure & 35 & 18.9 \\
medication & Diabetes & 6 & 3.2 \\
& Depression/anxiety & 9 & 4.9 \\
for which the respondents were receiving & Heart disease & High cholesterol & 5.4 \\
& Asthma, trouble breathing & 10 & 7.0 \\
Number of & Cancer & 5 & 2.7 \\
prescription drugs & Thyroid problems & 0 & 0.0 \\
& Other diseases & 5 & 2.7 \\
& $0-2$ & 26 & 14.1 \\
Type of health insurance & $3-5$ & 166 & 89.7 \\
preceding year & $6-8$ & 13 & 7.1 \\
& $1-5$ times & 6 & 3.2 \\
\hline Number of annual visits to the nurse in the & $6-10$ times & 152 & 82.2
\end{tabular}

\section{Satisfaction with the work of nurses in primary health care}

The satisfaction assessment scale for the assessment of patient satisfaction with nurses in primary health care includes three domains: patient satisfaction (18 items), communication (4 items) and accessibility (4 items). As shown in table 3 on the tested sample, the internal consistency coefficient for the patient satisfaction domain is Cronbach $\alpha=0.950$, for the communication domain it is Cronbach $\alpha=0.932$, and for the accessibility domain it is Cronbach $\alpha=0.810$. The obtained results show a high internal reliability of the instrument, both on the individual domains and on the whole scale (Cronbach $\alpha=0.966$ ). Testing the normality of distributions across domains and on the overall scale was done using the
Kolmogorov-Smirnov test. According to the obtained results, the tested distributions deviate statistically significantly from the normal distribution, so it is justified to use non-parametric statistical procedures in further processing.

\section{Patient satisfaction domain}

Data presented in table 4 shows that the majority of respondents answered all statements by agreeing or fully agreeing with them. Since the statements have a positive orientation, this supports the conclusion that the respondents are generally satisfied with nurses' work and service. 
Table 3. Internal reliability and testing the normality of distributions

\begin{tabular}{|c|c|c|c|c|c|c|c|c|}
\hline Domain & Number of items & \multicolumn{3}{|c|}{ Number of respondents } & \multicolumn{2}{|c|}{ Cronbach $\alpha$} & K-S Z & $\boldsymbol{p}$ \\
\hline Patient satisfaction & 18 & \multicolumn{3}{|c|}{185} & \multicolumn{2}{|c|}{0.950} & 1.676 & 0.001 \\
\hline Accessibility & 4 & \multicolumn{3}{|c|}{185} & \multicolumn{2}{|c|}{0.810} & 2.327 & 0.001 \\
\hline Communication & 4 & \multicolumn{3}{|c|}{185} & \multicolumn{2}{|c|}{0.932} & 3.036 & 0.001 \\
\hline Scale overall & 26 & \multicolumn{3}{|c|}{185} & \multicolumn{2}{|c|}{0.966} & 1.689 & 0.007 \\
\hline \multirow{2}{*}{\multicolumn{2}{|c|}{ Patient satisfaction }} & \multicolumn{5}{|c|}{ Number $(\%)$ of respondents } & \multirow[b]{2}{*}{ Total } & \multirow{2}{*}{$\begin{array}{c}\text { Median } \\
\text { (interquartile } \\
\text { range) }\end{array}$} \\
\hline & & 1 & 2 & 3 & 4 & 5 & & \\
\hline I was satisfied wi & my visit to the nurse. & $\begin{array}{c}2 \\
(1.1)\end{array}$ & $\begin{array}{c}6 \\
(3.2)\end{array}$ & $\begin{array}{l}15 \\
(8.1)\end{array}$ & $\begin{array}{c}65 \\
(35.1)\end{array}$ & $\begin{array}{c}97 \\
(52.4)\end{array}$ & $\begin{array}{l}185 \\
(100)\end{array}$ & $5(4-5)$ \\
\hline I will probably recom & end this nurse to others. & $\begin{array}{c}4 \\
(2.2)\end{array}$ & $\begin{array}{c}8 \\
(4.3)\end{array}$ & $\begin{array}{c}20 \\
(10.8)\end{array}$ & $\begin{array}{c}61 \\
(33.0)\end{array}$ & $\begin{array}{c}92 \\
(49.7)\end{array}$ & $\begin{array}{c}185 \\
(100)\end{array}$ & $4(4-5)$ \\
\hline $\begin{array}{r}\text { In the future, I will p } \\
\text { appointmer }\end{array}$ & $\begin{array}{l}\text { bably schedule another } \\
\text { with the nurse. }\end{array}$ & $\begin{array}{c}5 \\
(2.7)\end{array}$ & $\begin{array}{c}8 \\
(4.3)\end{array}$ & $\begin{array}{c}22 \\
(11.9)\end{array}$ & $\begin{array}{c}55 \\
(29.7)\end{array}$ & $\begin{array}{c}95 \\
(51.4)\end{array}$ & $\begin{array}{l}185 \\
(100)\end{array}$ & $5(4-5)$ \\
\hline The nurse did not ru & when working with me. & $\begin{array}{c}9 \\
(4.9)\end{array}$ & $\begin{array}{l}17 \\
(9.2)\end{array}$ & $\begin{array}{c}22 \\
(11.9)\end{array}$ & $\begin{array}{c}69 \\
(37.3)\end{array}$ & $\begin{array}{c}68 \\
(36.8)\end{array}$ & $\begin{array}{l}185 \\
(100)\end{array}$ & $4(3-5)$ \\
\hline I would prefer to see & $\begin{array}{l}\text { he nurse rather than the } \\
\text { ctor. }\end{array}$ & $\begin{array}{c}13 \\
(7.0)\end{array}$ & $\begin{array}{c}31 \\
(16.8)\end{array}$ & $\begin{array}{c}46 \\
(24.9)\end{array}$ & $\begin{array}{c}45 \\
(24.3)\end{array}$ & $\begin{array}{c}50 \\
(27.0)\end{array}$ & $\begin{array}{l}185 \\
(100)\end{array}$ & $4(3-5)$ \\
\hline The nurse is a ski & health practitioner. & $\stackrel{2}{2}$ & $\begin{array}{l}11 \\
(5.9)\end{array}$ & $\begin{array}{c}22 \\
(11.9)\end{array}$ & $\begin{array}{c}61 \\
(33.0)\end{array}$ & $\begin{array}{c}89 \\
(48.1)\end{array}$ & $\begin{array}{l}185 \\
(100)\end{array}$ & $4(4-5)$ \\
\hline $\begin{array}{r}\text { The nurse discusses tr } \\
\text { drugs to }\end{array}$ & $\begin{array}{l}\text { tment methods other than } \\
\text { lve my issue. }\end{array}$ & $\begin{array}{c}13 \\
(7.0)\end{array}$ & $\begin{array}{c}24 \\
(13.0)\end{array}$ & $\begin{array}{c}40 \\
(21.6)\end{array}$ & $\begin{array}{c}70 \\
(37.8)\end{array}$ & $\begin{array}{c}38 \\
(20.5)\end{array}$ & $\begin{array}{l}185 \\
(100)\end{array}$ & $4(3-4)$ \\
\hline I am satisfied with th & way the nurse treats me. & $\begin{array}{c}6 \\
(3.2)\end{array}$ & $\begin{array}{c}6 \\
(3.2)\end{array}$ & $\begin{array}{c}15 \\
(8.1)\end{array}$ & $\begin{array}{c}58 \\
(31.4)\end{array}$ & $\begin{array}{c}100 \\
(54.1)\end{array}$ & $\begin{array}{l}185 \\
(100)\end{array}$ & $5(4-5)$ \\
\hline $\begin{array}{r}\text { I was satisfied with } t \\
\text { nurse } s \mid\end{array}$ & $\begin{array}{l}\text { amount of time that the } \\
\text { nt with me. }\end{array}$ & $\begin{array}{c}3 \\
(1.6)\end{array}$ & $\begin{array}{c}7 \\
(3.8)\end{array}$ & $\begin{array}{c}18 \\
(9.7)\end{array}$ & $\begin{array}{c}68 \\
(36.8)\end{array}$ & $\begin{array}{c}89 \\
(48.1)\end{array}$ & $\begin{array}{l}185 \\
(100)\end{array}$ & $4(4-5)$ \\
\hline The nu & e is caring. & $\stackrel{2}{2}$ & $\begin{array}{c}5 \\
(2.7)\end{array}$ & $\begin{array}{c}19 \\
(10.3)\end{array}$ & $\begin{array}{c}58 \\
(31.4)\end{array}$ & $\begin{array}{c}101 \\
(54.6)\end{array}$ & $\begin{array}{l}185 \\
(100)\end{array}$ & $5(4-5)$ \\
\hline The nurse is knowle & $\begin{array}{l}\text { geable about my health } \\
\text { sues. }\end{array}$ & & $\begin{array}{c}9 \\
(4.9)\end{array}$ & $\begin{array}{c}19 \\
(10.3)\end{array}$ & $\begin{array}{c}62 \\
(33.5)\end{array}$ & $\begin{array}{c}95 \\
(51.4)\end{array}$ & $\begin{array}{l}185 \\
(100)\end{array}$ & $5(4-5)$ \\
\hline I trus & the nurse. & $\begin{array}{c}3 \\
(1.6)\end{array}$ & $\begin{array}{c}5 \\
(2.7)\end{array}$ & $\begin{array}{c}12 \\
(6.5)\end{array}$ & $\begin{array}{c}60 \\
(32.4)\end{array}$ & $\begin{array}{c}105 \\
(56.8)\end{array}$ & $\begin{array}{l}185 \\
(100)\end{array}$ & $5(4-5)$ \\
\hline The nurse knows $w$ & en to consult the doctor. & & $\begin{array}{c}3 \\
(1.6)\end{array}$ & $\begin{array}{c}15 \\
(8.1)\end{array}$ & $\begin{array}{c}67 \\
(36.2)\end{array}$ & $\begin{array}{l}100 \\
(54.1)\end{array}$ & $\begin{array}{l}185 \\
(100)\end{array}$ & $5(4-5)$ \\
\hline The nurse listen $\epsilon$ & to what I had to say. & & $\begin{array}{c}6 \\
(3.2)\end{array}$ & $\begin{array}{c}23 \\
(12.4)\end{array}$ & $\begin{array}{c}61 \\
(33.0)\end{array}$ & $\begin{array}{c}95 \\
(51.4)\end{array}$ & $\begin{array}{l}185 \\
(100)\end{array}$ & $5(4-5)$ \\
\hline The nurse is intere & ed in my health issues. & $\begin{array}{c}3 \\
(1.6)\end{array}$ & $\begin{array}{c}7 \\
(3.8)\end{array}$ & $\begin{array}{c}28 \\
(15.1)\end{array}$ & $\begin{array}{c}64 \\
(34.6)\end{array}$ & $\begin{array}{c}83 \\
(44.9)\end{array}$ & $\begin{array}{l}185 \\
(100)\end{array}$ & $4(4-5)$ \\
\hline The nurs & respects me. & $\begin{array}{c}2 \\
(1.1)\end{array}$ & $\begin{array}{c}5 \\
(2.7)\end{array}$ & $\begin{array}{c}20 \\
(10.8)\end{array}$ & $\begin{array}{c}60 \\
(32.4)\end{array}$ & $\begin{array}{c}98 \\
(53.0)\end{array}$ & $\begin{array}{l}185 \\
(100)\end{array}$ & $5(4-5)$ \\
\hline I understand what t & nurse explained to me. & & $\begin{array}{c}4 \\
(2.2)\end{array}$ & $\begin{array}{c}16 \\
(8.6)\end{array}$ & $\begin{array}{c}67 \\
(36.2)\end{array}$ & $\begin{array}{c}98 \\
(53.0)\end{array}$ & $\begin{array}{l}185 \\
(100)\end{array}$ & $5(4-5)$ \\
\hline $\begin{array}{r}\text { The nurse explai } \\
\text { underst }\end{array}$ & $\begin{array}{l}\text { ed things to me in an } \\
\text { ndable way. }\end{array}$ & $\begin{array}{c}2 \\
(1.1)\end{array}$ & $\begin{array}{c}5 \\
(2.7)\end{array}$ & $\begin{array}{c}19 \\
(10.3)\end{array}$ & $\begin{array}{c}61 \\
(33.0)\end{array}$ & $\begin{array}{c}98 \\
(53.0)\end{array}$ & $\begin{array}{l}185 \\
(100)\end{array}$ & $5(4-5)$ \\
\hline
\end{tabular}




\section{Accessibility domain}

The data presented in table 5 shows that most respondents positively assess the accessibility and availability of the nurse, and the most common answers are agreement and full agreement with the content of the statement. However, it should be noted that a larger number of respondents expressed hesitancy ("not sure") in agreeing with the statements concerning the possibility of arranging a suitable appointment with the nurse ( $N=38 ; 20.5 \%)$ and that arranging an appointment with the nurse is easier than with a doctor ( $N=43 ; 23.2 \%)$.

\section{The Communication domain}

According to the data in table 6, the respondents are positively oriented and mostly satisfied with the manner and possibility of communicating with the nurse, and they answered mostly with "I fully agree" and "I agree".

\section{Differences in the individual domains and the overall scale according to respondent characteristics}

\section{Differences in patient satisfaction with regard to the respondents" age}

The Kruskal-Wallis test was used to examine the existence of differences between the domains of patient satisfaction with the work of nurses in primary health care and the overall scale with respect to the patients' age. According to the results shown in table 7, patients are satisfied with nurses' work (the median of the overall scale according to the age groups is in the interval between 4.2 and 4.5). A statistically significant difference between age groups was observed only for the accessibility domain $(p<0.05)$, with slightly less satisfied respondents in the age group of patients of between 26 and 40 years of age (median 3.8 and interquartile range 3.0 to 4.5 ) relative to other groups.

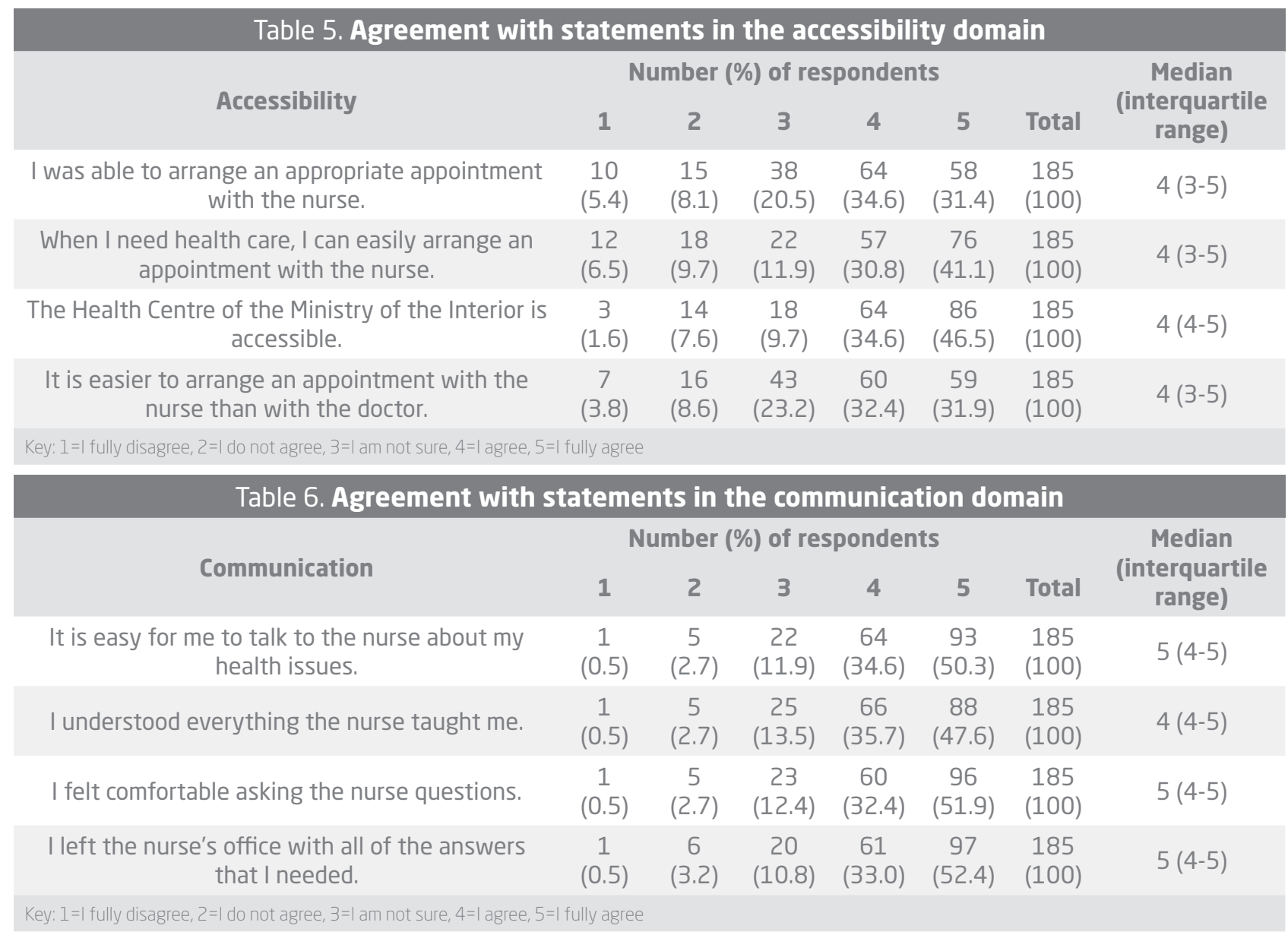




\begin{tabular}{|c|c|c|c|c|c|c|c|}
\hline Domain & $\begin{array}{c}\text { Age } \\
\text { (in years) }\end{array}$ & $\mathbf{N}$ & $\begin{array}{c}\text { Median } \\
\text { (interquartile range) }\end{array}$ & $M_{\text {rank }}$ & $\chi^{2}$ & df & p \\
\hline \multirow{4}{*}{ Patient satisfaction } & $18-25$ & 33 & $4.3(3.6-4.8)$ & 88.29 & \multirow{4}{*}{6.551} & \multirow{4}{*}{3} & \multirow{4}{*}{0.088} \\
\hline & $26-40$ & 47 & $4.2(3.4-4.7)$ & 77.98 & & & \\
\hline & $41-60$ & 85 & $4.4(3.9-4.8)$ & 100.33 & & & \\
\hline & $>60$ & 20 & $4.5(3.9-4.8)$ & 104.93 & & & \\
\hline \multirow{4}{*}{ Accessibility } & $18-25$ & 33 & $4.0(3.3-4.8)$ & 93.82 & \multirow{4}{*}{9.606} & \multirow{4}{*}{3} & \multirow{4}{*}{$0.022^{*}$} \\
\hline & $26-40$ & 47 & $3.8(3.0-4.5)$ & 74.59 & & & \\
\hline & $41-60$ & 85 & $4.0(3.6-4.6)$ & 97.82 & & & \\
\hline & $>60$ & 20 & $4.1(4.0-5.0)$ & 114.43 & & & \\
\hline \multirow{4}{*}{ Communication } & $18-25$ & 33 & $4.3(3.8-5.0)$ & 89.38 & \multirow{4}{*}{3.980} & \multirow{4}{*}{3} & \multirow{4}{*}{0.264} \\
\hline & $26-40$ & 47 & $4.0(3.8-5.0)$ & 82.33 & & & \\
\hline & $41-60$ & 85 & $4.5(4.0-5.0)$ & 97.40 & & & \\
\hline & $>60$ & 20 & $4.8(4.0-5.0)$ & 105.35 & & & \\
\hline \multirow{4}{*}{ Scale overall } & $18-25$ & 33 & $4.2(3.7-4.8)$ & 89.61 & \multirow{4}{*}{6.427} & \multirow{4}{*}{3} & \multirow{4}{*}{0.093} \\
\hline & $26-40$ & 47 & $4.1(3.3-4.7)$ & 77.86 & & & \\
\hline & $41-60$ & 85 & $4.4(3.9-4.8)$ & 99.50 & & & \\
\hline & $>60$ & 20 & $4.5(3.9-4.7)$ & 106.55 & & & \\
\hline
\end{tabular}

\section{Differences in patient satisfaction with regard to the respondents' gender}

The Mann-Whitney test was used to examine the existence of differences between the domains of patient satisfaction with the work of nurses in primary health care and the overall scale with respect to the patients' gender. According to the results shown in table 8 , patients are satisfied with nurses' work (the median of the overall scale for both groups is 4.3). No statistically significant differences were found between the examined groups by gender in the individual domains and the overall scale ( $p>0.05)$.

\section{Differences in patient satisfaction with regard to the respondents' level of education}

According to the results of the Kruskal-Wallis test shown in table 9, no significant differences were found in the examined domains or on the overall scale with regard to the respondents' level of education ( $p>0.05)$. The respondents are satisfied with the nurses' work. Given the values obtained, there is no statistically significant difference in the satisfaction of patients with the nurses' work with regard to the respondents' level of education.

\section{Differences in patient satisfaction with regard to the respondents' marital status}

According to the results of the Kruskal-Wallis test shown in table 10, no significant differences were found on the examined domains or on the overall scale with regard to the respondents' marital status $(p>0.05)$. The respondents are satisfied with the nurses' work; with regard to the resulting medians and the average rank, the respondents who are divorced or widowed are more satisfied with the nurses' work than other groups, which is confirmed by the greater number of responses indicating full agreement with the content of the statements offered. 


\begin{tabular}{|c|c|c|c|c|c|c|}
\hline Domain & Gender & $\mathbf{N}$ & $\begin{array}{c}\text { Median (interquartile } \\
\text { range) }\end{array}$ & $M_{\text {rank }}$ & $\mathbf{z}$ & $p$ \\
\hline \multirow{2}{*}{ Patient satisfaction } & Male & 126 & $4.4(3.8-4.8)$ & 93.44 & \multirow{2}{*}{-0.164} & \multirow{2}{*}{0.870} \\
\hline & Female & 59 & $4.4(3.8-4.8)$ & 92.06 & & \\
\hline \multirow{2}{*}{ Accessibility } & Male & 126 & $4.0(3.3-4.5)$ & 89.09 & \multirow{2}{*}{-1.462} & \multirow{2}{*}{0.144} \\
\hline & Female & 59 & $4.0(3.8-4.8)$ & 101.35 & & \\
\hline \multirow{2}{*}{ Communication } & Male & 126 & $4.5(4.0-5.0)$ & 92.16 & \multirow{2}{*}{-0.324} & \multirow{2}{*}{0.746} \\
\hline & Female & 59 & $4.5(4.0-5.0)$ & 94.79 & & \\
\hline \multirow{2}{*}{ Scale overall } & Male & 126 & $4.3(3.8-4.7)$ & 92.23 & \multirow{2}{*}{-0.286} & \multirow{2}{*}{0.775} \\
\hline & Female & 59 & $4.3(3.8-4.8)$ & 94.64 & & \\
\hline
\end{tabular}

\section{Table 9. The medians of the domains and the overall scale, as well as the testing of differences in patient satisfaction with regard to the patients' LEVEL OF EDUCATION ( $N=185)$}

\begin{tabular}{|c|c|c|c|c|c|c|c|}
\hline Domain & $\begin{array}{l}\text { Level of } \\
\text { education }\end{array}$ & $\mathbf{N}$ & $\begin{array}{c}\text { Median } \\
\text { (interquartile range) }\end{array}$ & $M_{\text {rank }}$ & $\chi^{2}$ & df & $p$ \\
\hline \multirow{4}{*}{ Patient satisfaction } & Primary & 3 & $3.8(3.4-4.6)$ & 60.67 & \multirow{4}{*}{5.027} & \multirow{4}{*}{3} & \multirow{4}{*}{0.170} \\
\hline & Secondary & 137 & $4.3(3.8-4.8)$ & 90.64 & & & \\
\hline & $\begin{array}{l}\text { Tertiary } \\
\text { (Bachelor) }\end{array}$ & 18 & $4.2(3.8-4.7)$ & 87.58 & & & \\
\hline & $\begin{array}{l}\text { Tertiary } \\
\text { (Master) }\end{array}$ & 27 & $4.6(4.1-4-8)$ & 112.20 & & & \\
\hline \multirow{4}{*}{ Accessibility } & Primary & 3 & $4.0(3.0-4.5)$ & 82.33 & \multirow{4}{*}{4.821} & \multirow{4}{*}{3} & \multirow{4}{*}{0.185} \\
\hline & Secondary & 137 & $4.0(3.3-4.5)$ & 88.88 & & & \\
\hline & $\begin{array}{l}\text { Tertiary } \\
\text { (Bachelor) }\end{array}$ & 18 & $4.3(3.6-4.5)$ & 96.19 & & & \\
\hline & $\begin{array}{l}\text { Tertiary } \\
\text { (Master) }\end{array}$ & 27 & $4.5(4.0-4.8)$ & 112.96 & & & \\
\hline \multirow{4}{*}{ Communication } & Primary & 3 & $4.0(3.0-5-0)$ & 73.67 & \multirow{4}{*}{3.943} & \multirow{4}{*}{3} & \multirow{4}{*}{0.268} \\
\hline & Secondary & 137 & $4.3(4.0-5.0)$ & 90.50 & & & \\
\hline & $\begin{array}{l}\text { Tertiary } \\
\text { (Bachelor) }\end{array}$ & 18 & $4.1(3.9-5.0)$ & 89.22 & & & \\
\hline & $\begin{array}{l}\text { Tertiary } \\
\text { (Master) }\end{array}$ & 27 & $5.0(4.0-5.0)$ & 110.37 & & & \\
\hline \multirow{4}{*}{ Scale overall } & Primary & 3 & $3.8(3.3-4.7)$ & 66.17 & \multirow{4}{*}{5.155} & \multirow{4}{*}{3} & \multirow{4}{*}{0.161} \\
\hline & Secondary & 137 & $4.3(3.8-4.7)$ & 90.06 & & & \\
\hline & $\begin{array}{l}\text { Tertiary } \\
\text { (Bachelor) }\end{array}$ & 18 & $4.2(3.8-4.7)$ & 89.33 & & & \\
\hline & $\begin{array}{l}\text { Tertiary } \\
\text { (Master) }\end{array}$ & 27 & $4.6(4.0-4.8)$ & 113.35 & & & \\
\hline
\end{tabular}




\section{Differences in patient satisfaction with regard to the respondents' employment status}

According to the results of the Kruskal-Wallis test shown in table 11 , no statistically significant differences were found in the examined domains or on the overall scale with regard to the respondents' employment status $(p>0.05)$. The respondents are satisfied with the nurses' work; with regard to the resulting medians and the average rank, the respondents who are temporarily employed or are retired are more satisfied than other groups, which was confirmed by the greater number of responses indicating full agreement with the content of the statements offered.

\section{Differences in patient satisfaction with regard to the respondents' annual income}

According to the results of the Kruskal-Wallis test shown in table 11, significant differences were found in the examined domains, as well as on the overall scale with regard to the respondents' annual income ( $p>0.01)$. Taking into account the resulting medians and average ranks, satisfaction is more often present in respondents with an annual income in the range between 26.000 to 35.000 HRK and the range between 36.000 to 45.000 HRK, which is confirmed by a greater number of answers indicating full agreement with the content of the statements offered.

\begin{tabular}{|c|c|c|c|c|c|c|c|}
\hline Domain & Marital status & $\mathbf{N}$ & $\begin{array}{c}\text { Median } \\
\text { (interquartile } \\
\text { range) }\end{array}$ & $M_{\text {rank }}$ & $\chi^{2}$ & df & p \\
\hline \multirow{6}{*}{ Patient satisfaction } & Single & 37 & $4.2(3.6-4.7)$ & 85.53 & \multirow{6}{*}{4.713} & \multirow{6}{*}{5} & \multirow{6}{*}{0.452} \\
\hline & Married & 107 & $4.4(3.8-4.8)$ & 94.05 & & & \\
\hline & Divorced & 14 & 4.7 (4.1-4.9) & 118.32 & & & \\
\hline & Widowed & 7 & $4.4(3.6-4.7)$ & 96.07 & & & \\
\hline & Life partnership & 8 & $4.4(2.9-4.8)$ & 81.38 & & & \\
\hline & Other & 12 & $4.2(3.5-4.6)$ & 83.08 & & & \\
\hline \multirow{6}{*}{ Accessibility } & Single & 37 & $4.0(3.1-4.5)$ & 86.16 & \multirow{6}{*}{7.089} & \multirow{6}{*}{5} & \multirow{6}{*}{0.214} \\
\hline & Married & 107 & $4.0(3.5-4.5)$ & 90.79 & & & \\
\hline & Divorced & 14 & $4.4(4.0-5.0)$ & 122.36 & & & \\
\hline & Widowed & 7 & $4.5(3.8-5.0)$ & 119.14 & & & \\
\hline & Life partnership & 8 & $4.0(3.0-4.9)$ & 93.00 & & & \\
\hline & Other & 12 & $3.6(3.1-4.8)$ & 84.29 & & & \\
\hline \multirow{6}{*}{ Communication } & Single & 37 & $4.0(3.9-5.0)$ & 86.65 & \multirow{6}{*}{4.028} & \multirow{6}{*}{5} & \multirow{6}{*}{0.545} \\
\hline & Married & 107 & $4.5(4.0-5.0)$ & 94.23 & & & \\
\hline & Divorced & 14 & $4.9(4.0-5.0)$ & 111.96 & & & \\
\hline & Widowed & 7 & $4.8(3.8-5.0)$ & 100.29 & & & \\
\hline & Life partnership & 8 & $4.1(3.1-4.8)$ & 72.56 & & & \\
\hline & Other & 12 & $4.3(3.6-5.0)$ & 88.88 & & & \\
\hline \multirow{6}{*}{ Scale overall } & Single & 37 & $4.2(3.6-4.7)$ & 85.77 & \multirow{6}{*}{5.125} & \multirow{6}{*}{5} & \multirow{6}{*}{0.401} \\
\hline & Married & 107 & $4.3(3.9-4.8)$ & 93.18 & & & \\
\hline & Divorced & 14 & 4.7 (4.1-4.9) & 120.32 & & & \\
\hline & Widowed & 7 & $4.6(3.6-4.7)$ & 101.14 & & & \\
\hline & Life partnership & 8 & $4.3(2.9-4.8)$ & 83.44 & & & \\
\hline & Other & 12 & $4.2(3.5-4.7)$ & 83.42 & & & \\
\hline
\end{tabular}




\begin{tabular}{|c|c|c|c|c|c|c|c|}
\hline Domain & Employment status & $\mathbf{N}$ & $\begin{array}{c}\text { Median } \\
\text { (interquartile } \\
\text { range) }\end{array}$ & $M_{\text {rank }}$ & $\chi^{2}$ & df & $\boldsymbol{p}$ \\
\hline \multirow{7}{*}{ Patient satisfaction } & Unemployed & 26 & $4.0(3.0-4.6)$ & 70.12 & \multirow{7}{*}{8.956} & \multirow{7}{*}{6} & \multirow{7}{*}{0.176} \\
\hline & Employed full-time & 136 & $4.4(3.8-4.8)$ & 96.20 & & & \\
\hline & Employed part-time & 1 & $4.0(4.0-4.0)$ & 66.00 & & & \\
\hline & Temporarily employed & 5 & $4.6(4.0-4.7)$ & 100.70 & & & \\
\hline & Retired & 13 & $4.6(4.3-4.8)$ & 111.88 & & & \\
\hline & Self-employed & 3 & $3.9(3.4-4.9)$ & 83.50 & & & \\
\hline & Other & 1 & $3.4(3.4-3.4)$ & 24.50 & & & \\
\hline \multirow{7}{*}{ Accessibility } & Unemployed & 26 & $3.8(2.8-4.5)$ & 74.75 & \multirow{7}{*}{8.560} & \multirow{7}{*}{6} & \multirow{7}{*}{0.200} \\
\hline & Employed full-time & 136 & $4.0(3.5-4.5)$ & 94.16 & & & \\
\hline & Employed part-time & 1 & $4.0(4.0-4.0)$ & 86.50 & & & \\
\hline & Temporarily employed & 5 & $4.8(3.5-4.9)$ & 118.20 & & & \\
\hline & Retired & 13 & $4.3(4.0-4.8)$ & 116.73 & & & \\
\hline & Self-employed & 3 & $4.0(2.3-4.5)$ & 77.17 & & & \\
\hline & Other & 1 & $3.0(3.0-3.0)$ & 29.50 & & & \\
\hline \multirow{7}{*}{ Communication } & Unemployed & 26 & $4.0(3.2-5.0)$ & 72.69 & \multirow{7}{*}{12.168} & \multirow{7}{*}{6} & \multirow{7}{*}{0.058} \\
\hline & Employed full-time & 136 & $4.5(4.0-5.0)$ & 94.24 & & & \\
\hline & Employed part-time & 1 & $4.0(4.0-4.0)$ & 59.00 & & & \\
\hline & Temporarily employed & 5 & $5.0(3.9-5.0)$ & 111.20 & & & \\
\hline & Retired & 13 & $5.0(4.3-5.0)$ & 123.38 & & & \\
\hline & Self-employed & 3 & $4.0(4.0-5.0)$ & 88.67 & & & \\
\hline & Other & 1 & $3.0(3.0-3.0)$ & 14.00 & & & \\
\hline \multirow{7}{*}{ Scale overall } & Unemployed & 26 & $3.8(3.0-4.7)$ & 70.75 & \multirow{7}{*}{9.223} & \multirow{7}{*}{6} & \multirow{7}{*}{0.161} \\
\hline & Employed full-time & 136 & $4.3(3.8-4.8)$ & 95.75 & & & \\
\hline & Employed part-time & 1 & $4.0(4.0-4.0)$ & 67.00 & & & \\
\hline & Temporarily employed & 5 & $4.6(4.0-4.7)$ & 103.10 & & & \\
\hline & Retired & 13 & $4.6(4.3-4.7)$ & 114.81 & & & \\
\hline & Self-employed & 3 & $4.0(3.3-4.8)$ & 81.50 & & & \\
\hline & Other & 1 & 3.3 (3.3-3.3) & 24.00 & & & \\
\hline
\end{tabular}

\section{Discussion}

Patient satisfaction is not just a legitimate demand, but also an important and desirable outcome of every treatment $(22,23)$. In this study conducted on patients, it can be concluded that patients are satisfied with the work of the nurse in primary care. 97 respondents (52.4\%) fully agree and 65 respondents
(35.1\%) agree with the statement "I was satisfied with my visit to the nurse".

Research conducted worldwide on patient satisfaction with the work of nurses shows that patients are generally satisfied with the care provided by nurses. A study conducted in Ireland using the EUROPEP form with questions related to politeness, careful listening, explaining procedures and assistance pro- 


\begin{tabular}{|c|c|c|c|c|c|c|c|}
\hline Domain & Annual income & $\mathbf{N}$ & $\begin{array}{c}\text { Median } \\
\text { (interquartile } \\
\text { range) }\end{array}$ & $M_{\text {rank }}$ & $\chi^{2}$ & df & $\boldsymbol{p}$ \\
\hline \multirow{6}{*}{$\begin{array}{c}\text { Patient } \\
\text { satisfaction }\end{array}$} & $<$ than 15.000 & 37 & $3.9(3.2-4.6)$ & 70.18 & \multirow{6}{*}{14.989} & \multirow{6}{*}{5} & \multirow{6}{*}{$0.006^{\star *}$} \\
\hline & $15.000-25.000$ & 1 & 3.8 (3.8-3.8) & 47.00 & & & \\
\hline & $26.000-35.000$ & 10 & $4.6(4.3-4.8)$ & 117.10 & & & \\
\hline & $36.000-45.000$ & 5 & 4.7 (4.1-4.9) & 120.80 & & & \\
\hline & $46.000-55.000$ & 19 & 3.9 (3.1-4.7) & 75.79 & & & \\
\hline & $>$ than 60.000 & 113 & $4.4(3.9-4.8)$ & 100.41 & & & \\
\hline \multirow{6}{*}{ Accessibility } & $<$ than 15.000 & 37 & $3.8(2.6-4.3)$ & 69.78 & \multirow{6}{*}{21.291} & \multirow{6}{*}{5} & \multirow{6}{*}{$0.010^{* *}$} \\
\hline & $15.000-25.000$ & 1 & 3.3 (3.3-3.3) & 40.00 & & & \\
\hline & $26.000-35.000$ & 10 & $4.8(4.3-5.0)$ & 143.05 & & & \\
\hline & $36.000-45.000$ & 5 & $4.5(3.1-5.0)$ & 115.10 & & & \\
\hline & $46.000-55.000$ & 19 & $3.8(3.0-4.5)$ & 74.95 & & & \\
\hline & $>$ than 60.000 & 113 & $4.0(3.8-4.5)$ & 98.70 & & & \\
\hline \multirow{6}{*}{ Communication } & $<$ than 15.000 & 37 & $4.0(3.3-5.0)$ & 74.74 & \multirow{6}{*}{15.025} & \multirow{6}{*}{5} & \multirow{6}{*}{$0.001^{* *}$} \\
\hline & $15.000-25.000$ & 1 & $4.0(4.0-4.0)$ & 59.00 & & & \\
\hline & $26.000-35.000$ & 10 & $5.0(4.0-5.0)$ & 121.30 & & & \\
\hline & $36.000-45.000$ & 5 & $5.0(4.1-5.0)$ & 117.70 & & & \\
\hline & $46.000-55.000$ & 19 & $4.0(3.0-5.0)$ & 69.89 & & & \\
\hline & $>$ than 60.000 & 113 & $4.5(4.0-5.0)$ & 99.57 & & & \\
\hline \multirow{6}{*}{ Scale overall } & $<$ than 15.000 & 37 & $3.8(3.0-4.7)$ & 69.95 & \multirow{6}{*}{16.460} & \multirow{6}{*}{5} & \multirow{6}{*}{$0.010^{\star *}$} \\
\hline & $15.000-25.000$ & 1 & 3.8 (3.8-3.8) & 44.00 & & & \\
\hline & $26.000-35.000$ & 10 & 4.6 (4.3-4.9) & 123.90 & & & \\
\hline & $36.000-45.000$ & 5 & $4.7(4.0-4.6)$ & 119.00 & & & \\
\hline & $46.000-55.000$ & 19 & $4.0(3.2-4.6)$ & 74.71 & & & \\
\hline & $>$ than 60.000 & 113 & $4.4(4.0-4.8)$ & 100.71 & & & \\
\hline
\end{tabular}

vided by a nurse indicates that patients are satisfied with the work of nurses (9). In our study, the patients rated the actions of nurses regarding listening to patients and explaining procedures positively. This is indicated by the answers to the statements: 156 (84.4\%) respondents fully agree or agree with the statement "the nurse listened to what I had to say", whereas $159(86 \%)$ respondents fully agree or agree with the statement "the nurse explained things to me in an understandable way".

Several studies from eight European countries (Norway, Sweden, Denmark, the United Kingdom, the
Netherlands, Germany, Portugal and Ireland) examined medical-technical care, the doctor-patient relation, information sharing, availability, accessibility and the organization of the service. Aspects of general health care were rated highest, while waiting for a consultation, assistance with emotional problems caused by health issues and concerns about treatment costs (9) were rated lower.

Studies done in Canada and New Zealand used the Thrasher and Purc-Stephenson instrument for the measurement of satisfaction and acceptance of health care provided by the nurse. Patients were 
generally satisfied with the provided care and participation in the treatment (10).

A 1995 USA study on patient satisfaction with the care of nurses, utilizing the Di Tomasso-Willard questionnaire, showed that $97 \%$ of the patients were satisfied with the nurses' services (11).

Comparisons between nurses and other health care providers in America found no significant difference between the patient's baseline characteristics and health status (12).

In Croatia, several studies have been conducted to determine patients' satisfaction levels with the work of primary health care providers. A study conducted in 100 general/ family practitioners' offices in the area of Istria, Primorje-Gorski Kotar, Međimurje, Osijek-Baranja and Vukovar-Srijem counties found that most patients were satisfied with the services they received at the family physician's office (4).

A study has been conducted in the Rovinj, Poreč, Umag, Labin, Opatija, Čakovec, Đakovo and Vinkovci areas on the quality of service. There were problems in conducting the survey, because out of 10.000 distributed questionnaires, a large number of the questionnaires was not filled in. In some offices, surveys were not conducted even though the offices had agreed to participate in the survey. Despite implementation problems, researchers were satisfied with the results because they pointed out problems that we are often not even aware of, and which most patients will not openly tell us about (13).

In Croatia, surveys conducted at family physicians' offices provide information on the opinions of patients, where the majority of them is satisfied with the service they receive, while in some settings, dissatisfaction does not exceed $50 \%$ of respondents (13). In most offices, waiting times are too long, the main reasons being too many patients, non-implementation of a patient appointment system, a large number of repeated examinations caused by lengthy processing and lengthy administrative procedures (13).

More than $60 \%$ of respondents at the Ministry of the Interior's Health Centre responded to the statements about the possibility of setting up an appointment by fully agreeing and agreeing; while 119 (64.3\%) respondents fully agree of agree with the possibility of setting up an appointment with the nurse. The patient appointment system is possible by telephone at a time specified for setting up patient appointments.
It is also possible to set up appointments via e-mail and SMS.

A significant difference between the domains of satisfaction with the work of nurses according to gender was determined to a slightly lesser extent in respondents in the age group of between 26 and 40 years of age. Also, the values obtained show there is no statistically significant difference in the patients' satisfaction with the nurses' work with regard to the respondents' level of education. Using the same research instrument, Novaković obtained results showing that respondents with tertiary (Master) degrees are more satisfied with nurses' services, but at the same time respondents with primary education were also satisfied with the services of the nurse (4). According to the obtained results, a statistically significant difference between the respondents' satisfaction with the work of nurses according to annual income is more pronounced in respondents with an annual income of between 26.000 and 35.000 HRK and in the range between 36.000 and 45.000 HRK. Novaković did not obtain these income differences in her study (4).

Agosta states that studies measuring patient satisfaction give positive results because of the impact of nurses' communication (14). Nurses have a major role in communicating with patients, not only because they are the first to meet and register the patient, but also because the patients themselves have a closer relationship with the nurse than with the doctor. It is easier for patients to talk about their issues with nurses, because they assume that nurses know and understand them better. Successful communication promotes a faster and more accurate diagnosis, greater patient satisfaction and better adherence to health recommendations and instructions (15).

\section{Conclusion}

The results of this study show that the patients who use the Health Centre of the Ministry of the Interior of the Republic of Croatia are satisfied with the work of nurses in primary health care. There is no significant difference in patient satisfaction with the work of nurses in primary care with respect to the 
patients' gender, marital status, working status and level of education.

There is a significant difference in patient satisfaction with the work of nurses in primary care with respect to the patients' age. The respondents in the age group of between 26 and 40 years of age are slightly less satisfied.

There is a significant difference in patient satisfaction with the work of nurses in primary care with respect to the patients' annual income. Satisfaction is more pronounced among respondents with an annual income of between 26.000 and 35.000 HRK and in the range between 36.000 and 45.000 HRK.

The data obtained through this study of patient satisfaction is not representative enough to serve as a decision-making base on a large scale, but is informative and adequate for the creation of an organizational system that puts the patient at the centre of attention. Measuring patient satisfaction should become one of the usual methods of our work, pointing out the necessary changes and showing patients that we care about their opinions.

\section{References}

1. Zakon o zdravstvenoj zaštiti. Narodne novine 100/2018. Croatian.

2. Pravilnik o standardima kvalitete zdravstvene zaštite i načinu njihove primjene. Narodne novine 79/2011. Croatian.

3. Pravilnik o akreditacijskim standardima za bolničke zdravstvene ustanove. Narodne novine 31/2011. Croatian.

4. Novaković J. Zadovoljstvo pacijenata radom medicinskih sestara/tehničara u primarnoj zdravstvenoj zaštiti [diplomski rad]. Osijek: Medicinski fakultet Osijek; 2017. Croatian.

5. Gašpert M. Zadovoljstvo bolesnika pruženom zdravstvenom skrbi u dnevnim bolnicama [diplomski rad]. Osijek: Medicinski fakultet Osijek; 2017. Croatian.

6. Dimova R, Stoyanova R, Keskinova D. The EUROPEP questionnaire for patient's evaluation of general practice care: Bulgarian experience. Croat Med J. 2017;58(1):63-74.

7. Gavran L, Jašarević $E$, Hasanica N. Patient satisfaction with primary care: are there differences between the approaches in family and general medicine? Med Glas (Zenica). 2013;10(2):379-84.

8. Spasojevic N, Hrabac B, Huseinagic S. Patient's Satisfaction with Health Care: a Questionnaire Study of Different Aspects of Care. Mater Sociomed. 2015;27(4):220-4.

9. Grol R, Wensing M. Patients Evaluate General/Family Practice: The EUROPEP Instrument. Nijmegen: Center for Quality of Care Research; 2000.

10. Gagan MJ, Maybee P. Patient satisfaction with Nurse Practitioner care in primary care settings. Aust J Adv Nurs. 2011;28:12-9.

11. Larrabee JH, Ferri JA, Hartig MT. Patient Satisfaction with Nurse Practitioner Care in Primary Care. J Nurs Care Qual.1997;11(5):9-14.

12. Hooker RS, Cipher DJ, Sekscenski E. Patient Satisfaction with Physician Assistant, Nurse Practitioner, and Physician Care: a national Survey of Medicare Beneficiaries. JCOM. 2005;12:2.

13. Mazzi B, Krčmar N, Gržalja N, Ferlin D, Ivančić $A$, Grgurev Z, i sur. Mišljenje pacijenata o našem radu element u procjeni kvalitete. HČ|Z. 2007;3(10):1-14. Croatian.

14. Agosta LJ. Psychometric Evaluation of the Nurse Practitioner Satisfaction Survey (NPSS). J Nurs Meas. 2009;17(2):114-33.

15. Havelka M. Zdravstvena psihologija. Jastrebarsko: Naklada Slap; 1998. 


\section{ZADOVOLJSTVO PACIJENATA RADOM MEDICINSKE SESTRE / MEDICINSKOG TEHNIČARA U PRIMARNOJ ZDRAVSTVENO] ZAŠTITI}

\section{Sažetak}

Uvod. Zadovoljstvo pacijenata pruženom zdravstvenom njegom jedan je od važnih indikatora kvalitete zdravstvene skrbi i zadnjih se godina učestalo provode istraživanja na temu zadovoljstva pacijenata.

Cilj. Provedeno je prospektivno presječno istraživanje u Domu zdravlja Ministarstva unutarnjih poslova Republike Hrvatske u periodu od travnja do lipnja 2019. godine. Cilj istraživanja bio je ispitati zadovoljstvo pacijenata radom medicinskih sestara/tehničara u primarnoj zdravstvenoj zašiti.

Metode. Primijenjen je standardizirani upitnik Nursing Practitioner Satisfaction Survey, za koji smo dobili odobrenje autorice. $U$ istraživanju je sudjelovalo 200 pacijenata Doma zdravlja Ministarstva unutarnjih poslova Republike Hrvatske. U istraživanje su bili uključeni pacijenti koji su došli u ambulante Doma zdravlja i trebali usluge samo medicinskih sestara/ tehničara. Od 200 anketiranih pacijenata 185 anketa ispravno je ispunjenih, dok je 15 anketa bilo neispravno ispunjeno.

Rezultati. Pacijenti Doma zdravlja Ministarstva unutarnjih poslova Republike Hrvatske zadovoljni su radom medicinskih sestara/tehničara u primarnoj zdravstvenoj zaštiti. Ne postoji statistički značajna razlika u zadovoljstvu radom medicinskih sestara/tehničara u primarnoj zdravstvenoj zaštiti prema spolu, stručnoj spremi, bračnom te radnom statusu. Statistički je značajna razlika u zadovoljstvu pacijenata radom medicinskih sestara/tehničara prema dobi ispitanika, ne- zadovoljniji su ispitanici u dobnoj skupini od 26 do 40 godina (Kruskal-Wallisov test, $\mathrm{Me}=3,8$ ). Postoji statistički značajna razlika u zadovoljstvu pacijenata radom medicinskih sestara/tehničara u primarnoj zdravstvenoj zaštiti prema visini godišnjih prihoda ispitanika, gdje je zadovoljstvo u većoj mjeri prisutno kod ispitanika s godišnjim prihodima u rasponu od $26.000,00 \mathrm{kn}$ do $35.000,00 \mathrm{kn}$ i rasponu od $36.000,00 \mathrm{kn}$ do 45.000,00 kn (Kruskal-Wallisov test, $p<0,01$ ).

Zaključak. Pacijenti u ovom istraživanju zadovoljni su radom medicinskih sestara/tehničara u primarnoj zdravstvenoj zaštiti. Postoje značajne razlike s obzirom na dob i visinu godišnjih prihoda.

Ključne riječi: zadovoljstvo pacijenta, medicinska sestra / medicinski tehničar u primarnoj zdravstvenoj zaštiti, upitnici za mjerenje zadovoljstva pacijenata 